\title{
Parasite load, iNOS and cytokine profiles, and histopathological aspects of Leishmania infantum infection in dogs with different clinical presentations
}

\section{Tassia Cristina Bello de Vasconcelos ${ }^{1 *}$ (D) Sávio Freire Bruno ${ }^{1}$ Luisa Helena Monteiro de Miranda Fátima Conceição-Silva ${ }^{3}$ Vinícius Silva Belo ${ }^{4}$ Fabiano Borges Figueiredo $^{5}$}

\author{
1Programa de Pós-graduação em Medicina Veterinária, Universidade Federal Fluminense (UFF), 24230-340, Niterói, RJ, Brasil. E-mail: \\ tassia.vasconcelos@gmail.com. "Corresponding author. \\ ${ }^{2}$ Laboratório de Pesquisa Clínica em Dermatozoonoses em Animais Domésticos, Instituto Nacional de Infectologia Evandro Chagas, Fundação \\ Oswaldo Cruz, Rio de Janeiro, RJ, Brasil. \\ ${ }^{3}$ Laboratório de Imunoparasitologia, Instituto Oswaldo Cruz, Fundação Oswaldo Cruz, Rio de Janeiro, RJ, Brasil. \\ ${ }^{4}$ Universidade Federal de São João del-Rei, Divinópolis, MG, Brasil. \\ ${ }^{5}$ Laboratório de Biologia Celular, Instituto Carlos Chagas, Fundação Oswaldo Cruz, Curitiba, PR, Brasil.
}

ABSTRACT: Visceral leishmaniasis (VL) is a zoonotic disease with a canine urban reservoir in South America. Dogs from an endemic area within Brazil, which were naturally infected with Leishmania infantum, and those presenting severe clinical (SC), mild, or no clinical (MNC) disease, were evaluated. Parasite load, histopathology, and cytokine and iNOS mRNA expressions were assessed in the spleen and liver in order to determine the potential markers for disease susceptibility or resistance. As a result, dogs with both SC and MNC had high parasite loads; $I F N-\gamma$ was the most expressive cytokine in both organs, along with IL-6 and IL-4 being detected in the spleen and liver, and IL-10 only in liver. The hepatic tissue presented higher medians for IFN- $\gamma$ and IL-10, and was the main organ to produce cytokines with hepatic IL-10 suggesting a regulatory follow up. Granulomas were detected in both organs; however, when absent in spleen, they were associated with elevated IL-6 levels, thus highlighting the anti-inflammatory role of IL-6. Microscopic lesions in the spleen were predominantly characterized by an extensively disorganized white pulp and splenic response was suggested as sub optimized. Parasite load, tissue damage, and immunological response may vary in the dogs with similar clinical symptoms, which may not be a good parameter for assessing the animal's susceptibility to VL.

Key words: visceral leishmaniasis, immunopathology, canine infection, histopathology, canine cytokines.

Carga Parasitária, iNOS, citocinas e histopatologia na infecção por Leishmania infantum em cães com apresentações clínicas distintas

RESUMO: A Leishmaniose visceral (LV) é uma doença zoonótica com reservatório canino na América do Sul. Cães oriundos de área endemica brasileira, naturalmente infectados por Leishmania infantum, apresentando doença clínica severa (CS) ou doença branda ou ausente (BA) foram avaliados. Carga parasitária, histopatologia e expressão de mRNA de citocinas e iNOS foram analisados em baço e figado, buscando determinar possiveis marcadores de susceptibilidade ou resistência à doença. Como principais resultados, tanto cães CS como BA apresentaram alta carga parsitária. IFN- $\gamma$ foi a citocina mais expressiva em ambos os órgãos, sendo IL-6 e IL-4 também detectadas em baço e figado e IL-10 em figado. No tecido hepático foram encontradas as maiores medianas de IFN- $\gamma$ e IL-10, sendo o figado o principal órgão produtor de citocinas, com IL-10 sugerindo acompanhamento regulatório. Granulomas foram detectados em ambos os órgãos. Quando de sua ausência no baço, essa foi associada à elevação dos níveis de IL-6, salientando o papel anti-inflamatório dessa citocina. Alterações microscópicas foram principalmente caracterizadas por extensiva desorganização de polpa branca, com a resposta esplência sendo sugerida como subotimizada. Carga parasitária, dano tecidual e resposta immune variaram mesmo em cães com quadros clínicos similares, não sendo, portanto, a análise clínica um bom parâmetro para avaliação de susceptibilidade animal à LV.

Palavras-chave: Leishmaniose visceral, imunopatologia, infecção canina, histopatologia, citocinas caninas.

\section{INTRODUCTION}

Visceral leishmaniasis (VL) is the most severe form of all leishmaniasis types (SUNDAR \& RAI, 2002). In South America, the disease has spread to the medium-sized and large urban areas revealing occurrence of zoonosis (WERNECK, 2014), with Leishmania infantum (syn = Leishmania chagasi) as the main etiological agent involved (DANTASTORRES, 2009).

In this case, the dog (Canis familiaris) is the main urban source of infection for the vector and transmission occurs via the bite of infected phlebotomine sand flies (WERNECK, 2014). The canine clinical spectrum can be diverse (MANCIANTI et al., 1988) and progression of 
leishmaniasis and its clinical manifestations result from complex interactions between $L$. infantum and the host immune response and its genetic background (MAIA \& CAMPINO, 2012).

The spleen and liver play a pivotal role in VL, being evident sites of interaction between the immune system and the Leishmania parasite (MAIA \& CAMPINO, 2012; SRIVASTAVA et al., 2016). All the obligatory cellular and humoral components enrolled in the immune response against the parasite are present in the spleen in large amounts (SRIVASTAVA et al., 2016). In the liver, several cells such as Kupffer (LOEUILLET et al., 2016; MELO et al., 2009; MOREIRA et al., 2016; RODRIGUES et al., 2016; SANT'ANA et al., 2007), T lymphocyte, and dendritic cells present interesting interactions (LOEUILLET et al., 2016; RODRIGUES et al., 2016).

In this context, the present study investigated the possible markers of susceptibility or resistance to visceral leishmaniasis. Therefore, we assessed the parasite load, histopathological profile, and cytokine and inducible nitric oxide synthase (iNOS) expressions in the spleen and liver, in conjunction with the clinical status of dogs naturally infected with L. infantum from a Brazilian endemic area.

\section{MATERIALS AND METHODS}

\section{Study design}

This is a cross-sectional study conducted with a convenience sample of 24 mongrel dogs from a Brazilian endemic area to assess the presence of canine visceral leishmaniasis (CVL) in the municipality of Barra Mansa, Southeastern Brazil. Animals were subjected to euthanasia, according to the Brazilian Ministry of Health (BRASIL, 2009), when the positive serological results for L. infantum via immunochromatographic rapid testdual path platform $\left(\mathrm{DPP}^{\circledR}\right)$-BioManguinhos ${ }^{\circledR} /$ FIOCRUZ and enzyme-linked immunosorbent assay (ELISA) were obtained from the Public Health Surveillance Offices. Dogs with a definitive diagnosis of leishmaniasis by a parasitological culture and isoenzymatic characterization of $L$. infantum were included in the study.

\section{Clinical evaluation and sample collection}

Dogs were classified based on their clinical signs and symptoms, suggestive of CVL, in two different groups according to de VASCONCELOS et al. (2016): animals with severe clinical disease (SC) and animals with mild or no clinical disease (MNC). They were euthanized with an intravenous overdose of thiopental sodium and were immediately subjected to autopsy. Three fragments from the spleen and the liver were collected immediately after their death and stored at $-196{ }^{\circ} \mathrm{C}$, in $10 \%$ formalin and in buffered saline solution, respectively, as required for each technique subsequently applied. In addition, for better appreciation of the infection process and to eliminate any doubts regarding the presence of Leishmania parasite, a comprehensive collection of fragments from different tissues was performed in the buffered saline solution for parasitological culture, this being considered as the gold diagnostic standard. Samples from the lymph nodes, skin, bone marrow, and organs of the reproductive system (glans penis, testicle, epididymis, and prostate in male dogs; mammary gland, vulva, vagina, and uterus in female dogs) were collected and subjected to parasitological culture with isoenzymatic characterization. Dogs were considered as positive when the infection by $L$. infantum was confirmed in at least one of these samples.

\section{Parasitological culture}

The biphasic Novy-McNeal-Nicolle (NNN) medium with Schneider medium as liquid phase plus $10 \%$ fetal bovine serum was used to seed the fragments stored in a buffered saline solution. These fragments were kept in biological oven at $26-28{ }^{\circ} \mathrm{C}$ and were examined weekly for 30 days by fresh examination to highlight the flagellated forms of Leishmania spp. Leishmania isolates were identified via multilocus enzyme electrophoresis for $L$. infantum species characterization (ALMEIDA et al., 2011).

\section{Histopathology and immunohistochemistry}

Tissue samples fixed in $10 \%$ formalin were subjected to routine histology processing and were stained with hematoxylin-eosin (HE) for histopathological evaluation. For both organs, the presence of granulomas (compact aggregates of activated mononuclear phagocytes) was evaluated. In the liver, the occurrence of nongranulomatous inflammation was classified as: portal (portal tracts infiltration/expansion by inflammatory cells) and lobular (foci of inflammatory cell aggregates within the lobular parenchyma). Presence of fibrosis and vacuolar changes were also assessed. In the spleen, the presence of perisplenitis and red pulp cell population were described. Additionally, the white pulp structural organization was analyzed according to SANTANA et al. (2008) as per the following categories: 1-well organized (WO), 2-slightly disorganized (SD), 3-moderately disorganized (MD), and 4-extensively disorganized (ED). 
The technique of anti-Leishmania immunohistochemistry was described elsewhere (DOS SANTOS et al., 2015). Positive controls comprised tissue sections, previously known as positive by both culture and immunohistochemistry, and additional sections of the same case were run in parallel by suppressing the primary antibody. In the positive cases, the parasite load was considered as the mean of the amastigote count from three different 40x magnification fields. Based on the detection of amastigotes in the tissue sections via immunohistochemistry, the stratification of samples with detectable and undetectable parasites was performed.

\section{Real-time PCR}

The samples frozen at $-196{ }^{\circ} \mathrm{C}$ were subjected to total RNA extraction using a combined protocol based on the use of TRIzol Reagent (Thermo Fisher Scientific) with the aid of the disperser ULTRA-TURRAX ${ }^{\circledR}$ T10 basic (IKA ${ }^{\circledR}$, Germany), according to the manufacturer's instructions until the phase separation with chloroform, followed by employment of the RNeasy Mini QIAcube Kit in a semi-automated Qiacube system (Qiagen). The total RNA obtained was subjected to reverse transcription using $200 \mathrm{U}$ of Moloney murine leukemia virus reverse transcriptase (Superscript II, Invitrogen), according to the manufacturer's instructions.

For the Real-Time PCR (RT-PCR), the canine housekeeping gene of the enzyme hypoxanthine phosphoribosyl transferase (HPRT) was used for reaction normalization. Primers and fluorogenic probes FAM-TAMRA for cytokines, iNOS enzyme, and HPRT, the RT-PCR employed, and the calculations of values were performed according to a previous study (DE VASCONCELOS et al., 2016), assessing the IFN- $\gamma$, IL-6, IL-10, IL-12p35, TNF- $\alpha$, and iNOS transcripts.

\section{Statistical analyses}

Both Kolmogorov-Smirnov test with Lilliefors significance correlation and the ShapiroWilk normality test indicated that quantitative variables were not normally distributed. Thus, Mann-Whitney test $\left(P_{M W}\right)$ was applied to evaluate the associations between the clinical groups and cytokine mRNA profile, clinical groups and parasite load, cytokine mRNA profile and histopathological findings (presence or absence), and between the profile of cytokines and parasite load (detectable or not detectable). The Wilcoxon test $\left(P_{w}\right)$ was adopted to analyze the associations between spleen and liver cytokine profiles, and between spleen and liver parasite load; and Pearson $\left(P_{P}\right)$ or Fisher $\left(P_{F}\right)$ chisquare tests, to evaluate the histopathology and the parasite load groups. Moreover, Spearman correlation (PSC) was applied to verify the associations between splenic and hepatic parasite loads, and related to the expression of cytokine mRNA, between themselves and according to parasite load. Graphs were plotted using GraphPad Prism 7 software.

\section{RESULTS}

\section{Clinical and parasitological results}

Twenty-four dogs were assessed, of which 19 presented severe clinical disease (SC), whereas five had mild or no clinical disease (MNC).

In the set of tissue samples examined, $79.17 \%(19 / 24)$ of the spleen samples and $75.00 \%$ $(18 / 24)$ of the liver samples were positive during the parasitological culture. All animals had positive culture results in at least one tissue analyzed and most of the negative results from the spleen and liver ( $4 / 5$ and $5 / 6$, respectively) belonged to animals with severe clinical signs of the disease.

Considering the identification of amastigotes via immunohistochemistry, the detection rates were $52.17 \%(12 / 23)$ and $56.52 \%(13 / 23)$ for spleen and liver samples, respectively. Parasite loads varied considerably among the individuals, with the mean ranging from no parasites detected to 1085 and 99.33 in spleen and liver samples, respectively.

Although, no significant differences were observed in the parasite load mean values between the clinical groups $\left(P_{m w}>0.05\right)$, these reached the mean values of 172.67 and 93 in spleen and liver of MNC animals, respectively.

\section{Histopathological results}

The splenic histopathological profile was assessed in 23 dogs. Microscopic findings were characterized by various degrees of white pulp disorganization (Figure 1): $8.70 \%(2 / 23)$ of the samples had SD white pulp, $43.48 \%$ (10/23) presented MD white pulp, and $47.83 \%(11 / 23)$ revealed ED white pulp. The five dogs belonging to the MNC clinical group presented MD or ED white pulp.

Perisplenitis was evidenced in $30.43 \%$ $(7 / 23)$ of the spleen samples, and granulomas were present in 56.52\% (13/23).

A significant association was reported between the presence of granulomas $\left(P_{f t}=0.010\right)$ and the group of detectable parasites via immunohistochemistry in the spleen. All splenic samples with undetectable 


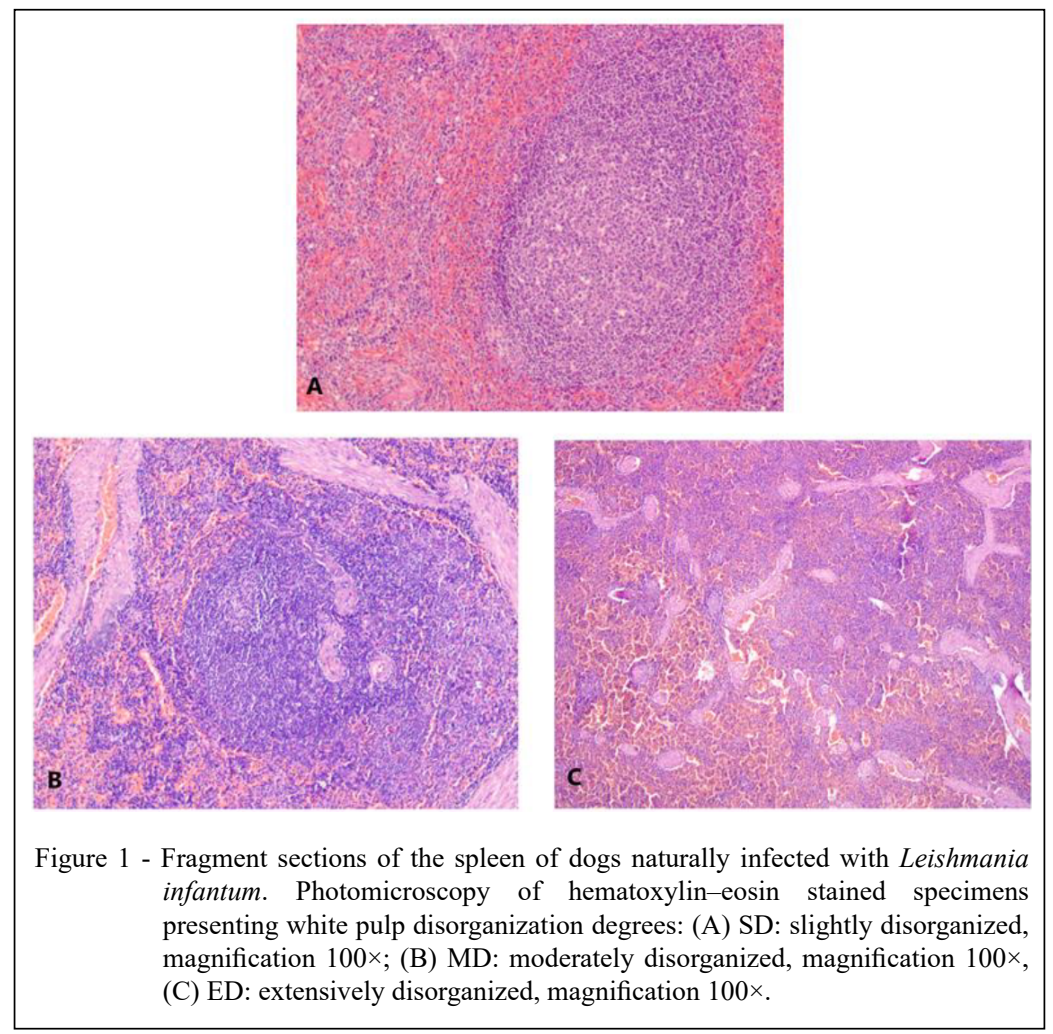

parasites $(n=11)$ via immunohistochemistry analysis revealed some disorganization degree of white pulp, ranging from moderate to extensively disorganized, and six of them presented positive results on the culture. No significant associations were identified $\left(P_{f t}>0.05\right)$ in the liver related to the granulomas and detectable parasites via immunohistochemistry.

Similarly, 23 liver samples were evaluated by histopathology. Nongranulomatous mononuclear inflammatory infiltrates were present in $91.30 \%$ $(21 / 23)$ of the liver samples. These infiltrates were mild in $61.90 \%(13 / 21)$, moderate in $28.57 \%(6 / 21)$, and intense in $9.52 \%(2 / 21)$ of the cases. From the two liver samples with intense infiltrate, one belonged to the SC group and the other to the MNC group. Portal distribution of the infiltrate alone was observed in $19.05 \%(4 / 21)$ of the samples and it was associated with lobular inflammation in $16 / 21$ cases (76.17\%). Plasma cells were present in 18 cases, either alone or associated with the macrophages and lymphocytes. Lymphoplasmacytic infiltrate was predominant in $52.38 \%(11 / 21)$ of the samples. Granulomatous infiltrate was present in $39.13 \%$ $(9 / 23)$, and vacuolar changes were observed in $30.43 \%(7 / 23)$ of the samples.
The main histopathological findings are presented in figures 1, 2 and 3.

\section{Expression profile of cytokines and iNOS}

IFN- $\gamma$ was the most expressive cytokine in both organs, presenting 17.93 and 8.12 as medians in liver and spleen, respectively. In particular, 9 liver sample values were higher than 30 , with the highest level reaching a 98.69 fold-increase in relation to its naïve counterpart. Moreover, IL-6 was detected, with 2.60 and 1.50 as median values and 26.6 and 14.15 as the highest levels in the spleen and liver, respectively.

The other cytokines and iNOS mRNAs had lower or no expression in both tissues. IL-4 reached 7.78 and 9.73 as the highest levels in the spleen and liver, respectively, and IL-10 attained 4.47 in the liver.

Hepatic IFN- $\gamma$ was higher in the SC group than that in the MNC group $\left(P_{m w}=0.046\right)$. Although, no other significant differences were observed in the other cytokine profiles and iNOS considering the clinical groups $\left(P_{m w}>0.05\right)$, the splenic IFN- $\gamma$ median was higher in the SC group and the maximum IL-4 values were observed in the $\mathrm{SC}$ group in both organs. The association between the main cytokines in the tissue samples and the clinical groups is presented in figure 4 . 


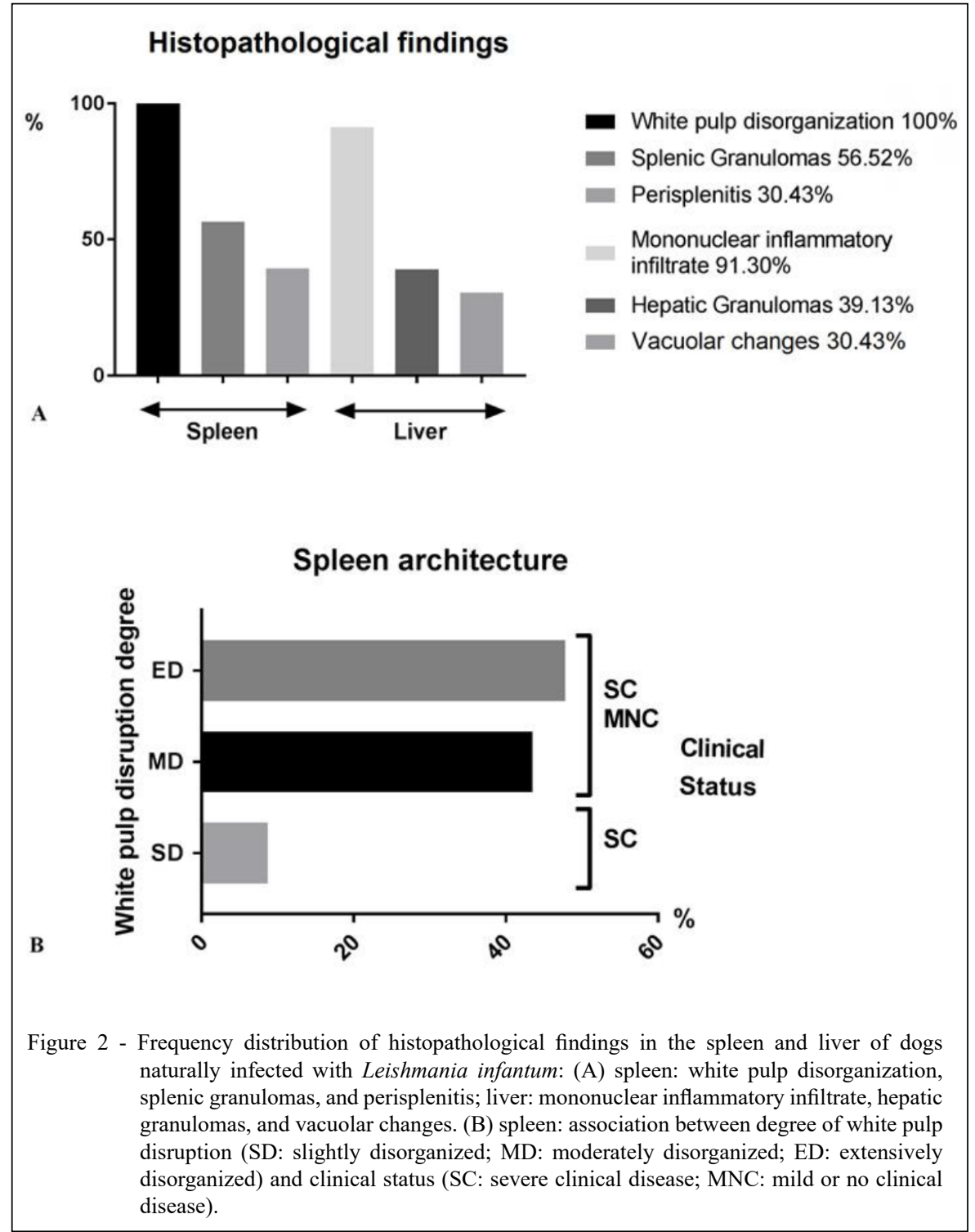

No significant association was observed between the parasitic load and cytokine profile in both organs evaluated $\left(P_{m w}>0.05 ; P_{s c}>0.05\right)$.

Among the cytokines, the following significant interactions were observed: negative correlations between IFN- $\gamma$ and IL- $6(\mathrm{r}=-0.416 ; P$ $=0.043)$, and IFN- $\gamma$ and IL-4 $\left(\mathrm{r}=-0.433 ; P_{s c}=0.035\right)$ in spleen; and positive correlations between IFN- $\gamma$ and IL-10 ( $\left.\mathrm{r}=0.471 ; P_{s c}=0.023\right)$ in liver.

Higher levels of IL-6 were reported in the spleen samples without granulomas $\left(P_{m w}=0.021\right)$. The medians of IFN- $\gamma$ were over two-fold higher in the spleen samples, and almost four times higher in the liver samples, in presence of granulomas (Figure 5).
As for the spleen and liver comparisons, IFN- $\gamma$ and IL-10 were higher in the spleen $\left(P_{w}=0.002\right.$ and $P_{w}<0.0001$, respectively), and no significant difference was observed between the parasitic loads of these organs $\left(P_{w}>0.05\right)$, with a positive correlation for association between the parasitic loads in spleen and liver $\left(\mathrm{r}=0.721 ; P_{s c}=0.000\right)$. The IFN- $\gamma$ and IL10 distribution per organ is presented in figure 6 .

\section{DISCUSSION}

In this study, serologically positive animals, with negative or undetectable parasitological results in the spleen, presented important IFN- $\gamma$ expression

Ciência Rural, v.49, n.10, 2019. 

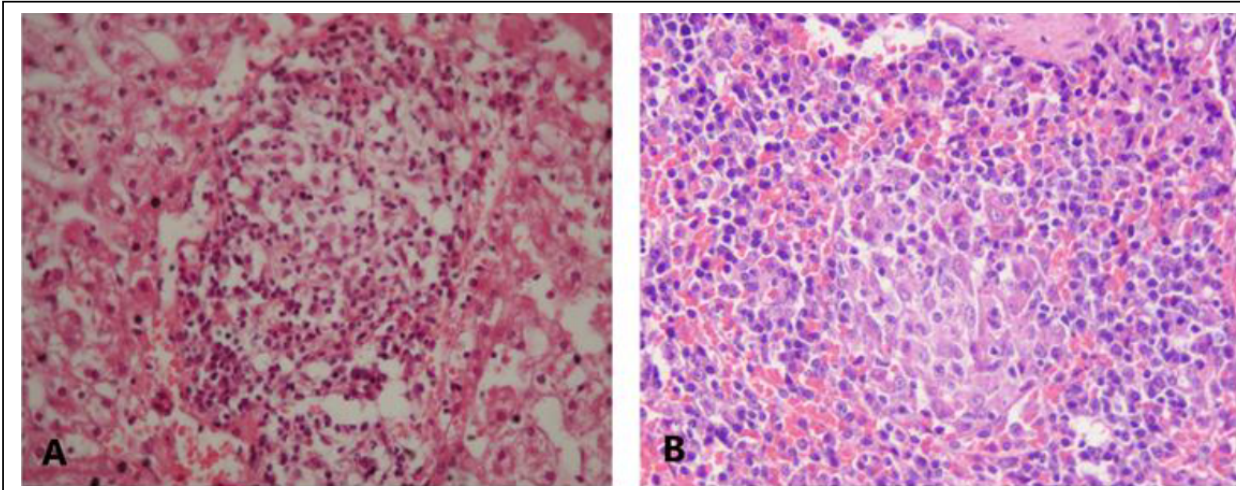

Figure 3 - Fragment sections of tissues of dogs naturally infected with Leishmania infantum. Photomicroscopy of hematoxylin-eosin stained specimens (A) hepatic granuloma, magnification 100×; (B) splenic granuloma, magnification $1000 \times$

and structural modifications in the splenic tissue, thereby suggesting a time lapse in the inflammatory process to reduce the parasitic load. In particular, in the murine model, the structural changes in the spleen occur during the chronic phase (RODRIGUES et al., 2016). Moreover, undetectable IL-10, as described in this study, may be related to a decrease in the parasite load, because inhibition of this cytokine activity leads to faster granuloma formation and parasite elimination in the murine model (NYLÉN \& KUMAR, 2012).

Nevertheless, this response can be suboptimal because the splenic architectural changes can lead to deficiency in cell interaction, which is essential for the effectiveness of the immune response (RODRIGUES et al., 2016). This deficiency would be a plausible reason for infection maintenance in the spleen during CVL; although, the granulomatous response was still associated with detectable parasites. Noteworthy, the parasite persistence may result in continued proinflammatory response, which causes exhaustion of the immune system and failure to generate appropriate CD4 T cell response (NYLÉN \& KUMAR, 2012). In contrast, the significant association between the absence of splenic granulomas (MAIA \& CAMPINO, 2012; NYLÉN \& KUMAR, 2012) and IL-6 levels corroborates the suggestion of this cytokine as a marker of active leishmaniasis disease in dogs (DE LIMA et al., 2007; DE VASCONCELOS et al., 2016), and highlights the possible anti-inflammatory role of IL-6 (SCHELLER et al., 2011). Moreover, IL-6 levels in human serum were strongly associated with death from visceral leishmaniasis (DOS SANTOS et al., 2016).

Predominance of IFN- $\gamma$ observed in both organs may be related, besides other associations, to a response by Th1 cells, whose predominance is associated with protection against CVL (GRADONI, 2015). The liver presented higher medians for IFN- $\gamma$ and IL-10 than the spleen and, in particular, Michelin and co-workers (MICHELIN et al., 2011) had already described the liver as the main cytokineproducing organ during infection, also corroborating the importance suggested by MAIA \& CAMPINO (2012) for hepatic tissue, considering it as one of the most relevant organs involved in the parasite-host interface during L. infantum infection.

Both IFN- $\gamma$ and IL- 6 detections indicate, among other aspects, a balance between the attempt to parasitic elimination by Th1 pathway and the disease in activity(CECÍLIO etal., 2014; DE VASCONCELOS et al., 2016; DE LIMA et al, 2007). Moreover, the negative correlation between these cytokines in the spleen highlights these dichotomous roles. Although, statistically insignificant, it should be emphasized that the highest level of IL-6 in splenic tissue was detected in a sample in which the amastigotes were not detected via immunohistochemistry. The negative correlation between the IL-6 levels and the presence of granulomas in spleen may reflect different timepoints in the course of the disease, with an early increase in the IL- 6 levels and the development of granuloma at chronic stages.

Nevertheless, the regulatory pathway by IL-10, which could be contributing to parasitic elimination failure and disease progression (RODRIGUES et al., 2016; TRINCHIERI, 2007), was not evident. Although other authors (CORREAA et al., 2007; LAGE et al., 2007) detected significant presence of IL-10 in the canine spleens and livers, its expression was not significant in the hepatic and 


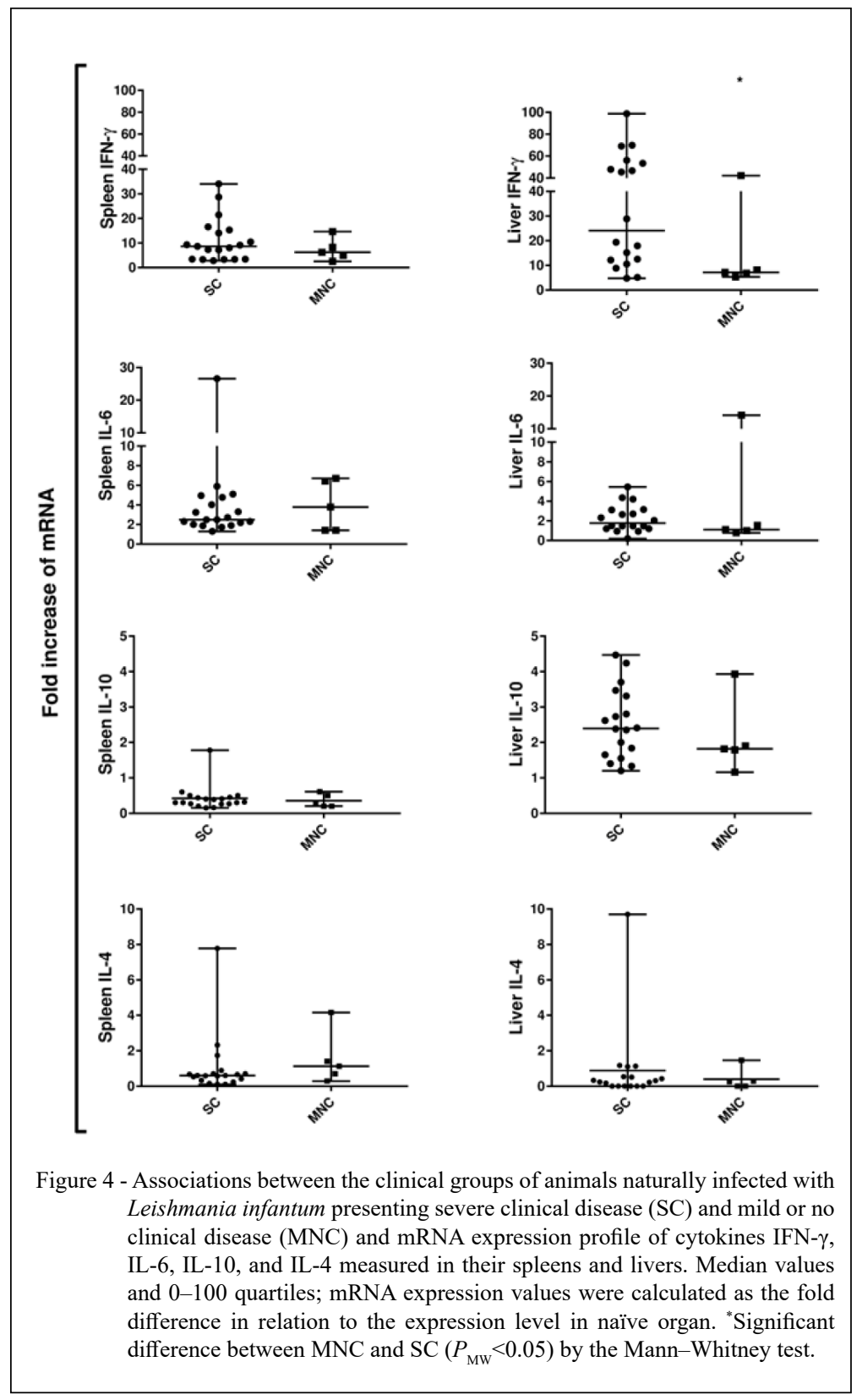

splenic tissues of the groups evaluated in this study. The IL-10 absence in the splenic tissue corroborates the findings of architecture disorganization, considering that this cytokine would collaborate with avoidance of the collateral damage caused by exaggerated inflammation (TRINCHIERI, 2007). Nevertheless; although at low levels, IL-10 detection in the hepatic tissue and its positive correlation with IFN$\gamma$ suggest that IL-10 follows up, in a regulatory manner, the expression level of pro-inflammatory IFN- $\gamma$.
In this context, IL-4 detection in this study corroborates parasite persistence (STRAUSSAYALIA et al., 2007) and reveals dichotomically negative correlation with IFN- $\gamma$ in the splenic tissue. IL-4 may indicate, among other factors, the activation of macrophages by the alternative pathway toward parasite survival (WANASEN \& SOONG, 2008). In addition, the possible anti-inflammatory role of IL-6 (SCHELLER et al., 2011) seems to contribute to parasitism and, interestingly, it was demonstrated

Ciência Rural, v.49, n.10, 2019. 


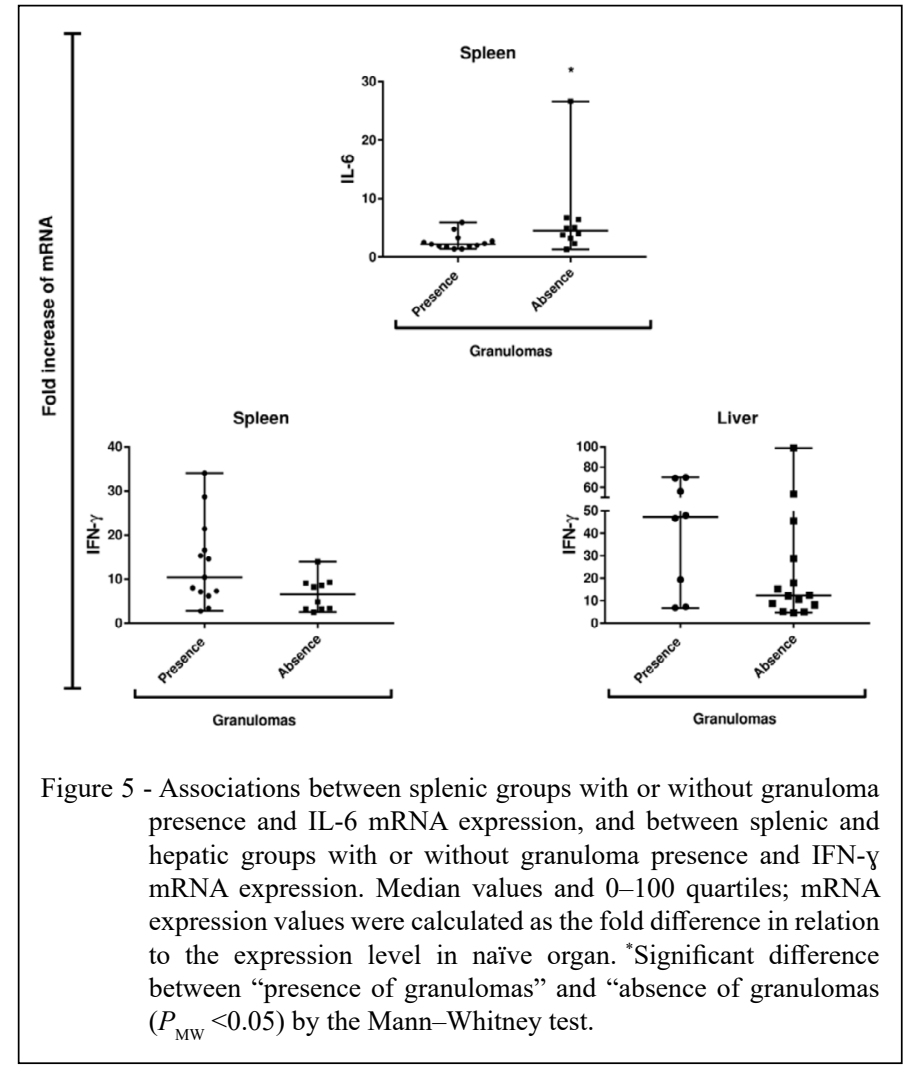

that monocytes differentiate in functionally impaired dendritic cells in the presence of IL-4 and IL-6 (HEGDE et al., 2004).

Moreover, the low- or not detection of iNOS presented herein indicates a reduction in the macrophage activation by the classic pathway, which would favor the subsequent parasite elimination by means of nitric oxide production (CECÍLIO et al., 2014; WANASEN \& SOONG, 2008).

Similarly, the low or no detection of IL-12 described in this study can reduce the maturation of $\mathrm{T}$ cells toward the response by Th1 cells that would produce more IFN- $\gamma$ for macrophage activation by the classic pathway (CECÍLIO et al., 2014). In particular, one of the main mechanisms used by Leishmania spp. to transpose the immune response of the host is to inhibit the production of IL-12, as well as to prevent dendritic cells from presenting the $\mathrm{T}$ cell antigen satisfactorily (SRIVASTAVA et al., 2016).

LIMA et al. (2014) associated splenic morphological changes with severe clinical illness in dogs infected with L. infantum; however, our results showed mildly symptomatic or asymptomatic animals with moderate to extensive splenic tissue disorganization, and with a relatively high parasite load. This high load in MNC animals eliminates the possibility of considering dog clinical status as a criterion for parasite susceptibility. In this sense, BORJA et al. (2016) also reported no significant association between the clinical manifestations and parasite load in the spleen of dogs naturally infected with L. infantum. Regarding hepatic analyses, Sant'ana et al. (2007) also did not find any significant differences between the parasite load in liver and canine clinical status, similarly to the results obtained for the liver samples in this study. These findings are still in accordance with our recent previous results on lymph node parasite load and clinical evaluation in dogs, which presented no significant difference (DE VASCONCELOS et al., 2016).

In fact, the immune response and granuloma formation in spleen is considered less effective than that in the liver during visceral leishmaniasis (ENGWERDA et al., 2004; KAYE \& BEATTIE, 2016). Although splenic architectural changes are constantly described in CVL, with well-organized and extremely disorganized white pulp being more well-established concepts, slight and moderate 


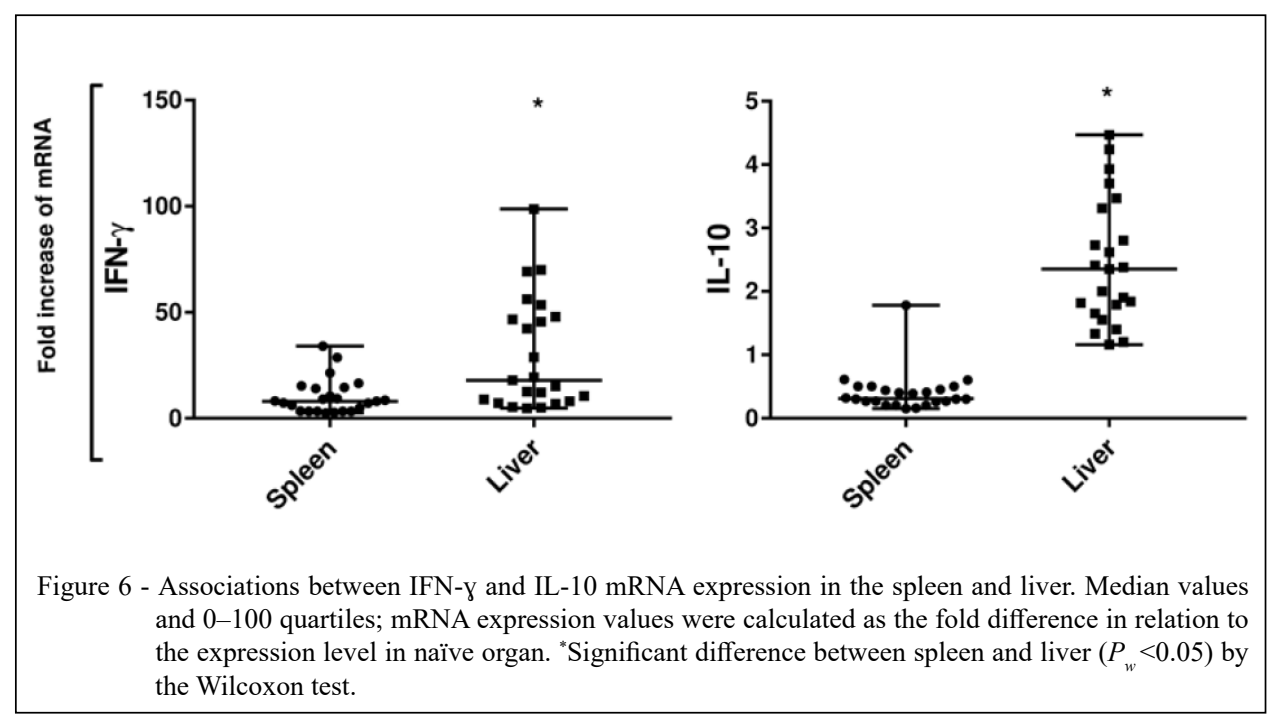

changes may be tricky and reflect either hyper- or hypoplastic processes (HERMIDA et al., 2018). The findings regarding white pulp disorganization and perisplenitis are consistent with those of previous studies on the canine host (CAVALCANTI et al., 2015; MAIA\& CAMPINO, 2012; SANT'ANAetal., 2008; TASCA et al., 2009). The relative increase in the number of lymphocytes, macrophages, granulocytes, and plasma cells highlights the involvement of these cell types in the immune response against Leishmania spp. (CECÍlIO et al., 2014; DE MENEZES et al., 2016; LIU \& UZONNA, 2012; LOEUILLET et al., 2016; NYLÉN \& KUMAR, 2012). DA SILVA et al. (2018) reported low CD4 lymphocyte levels in red pulp along with architectural disruption. This may lead to impaired splenic function and it is likely to explain higher fungal load and poor granuloma formation usually observed in the spleen. Likewise, the association between reduced levels of chemokines in the spleen and severe CVL (NASCIMENTO et al., 2013) suggests that splenic structural changes might be affecting the immune response in this organ, presumably because cellular migration mechanisms are compromised.

In fact, splenic architectural disruption has been related to increased severity in CVL (NASCIMENTO et al., 2013; LIMA et al., 2014; DA SILVA et al., 2018). Although, hyperplastic reaction is described in CVL, the architectural disorganization of the spleen seems related to hypoplastic changes and atrophy (SANTANA et al., 2008), that may lead to immune dysfunction and explain the increased severity described in CVL.
Since the evaluation of the cell types or other immunological markers in the present study relied only on H\&E-based morphology, the findings should be carefully interpreted. The immunohistochemical characterization of these cells should be encouraged to increase the accuracy of the results and to better understand the potential changes in splenic function. In the present study, splenic granulomas were significantly associated with the presence of parasites in this tissue, as previously described in splenic infection in cases of CVL (MOREIRA et al., 2016; SANT'ANA et al., 2008; TASCA et al., 2009), and have also been associated with disorganization of the splenic architecture (MOREIRA et al., 2016; TASCA et al., 2009), particularly in advanced cases of the disease (MOREIRA et al., 2016).

As for livers, mild mononuclear infiltrate with predominantly portal location was observed, which is in accordance with the findings by TORRES et al. (2016). Infiltrate composition with lymphocytes, plasma cells, and macrophages was described by previous studies (MELO et al., 2009; MOREIRA et al., 2016), along with the presence of vacuolar changes, which were recently reported by MOREIRA et al. (2016). In the present study, since the non granulomatous inflammation in the liver was not accompanied by hepatocellular necrosis or fibrosis, it is reasonable to assume that it is consistent with a nonspecific reactive response to an extra-hepatic injury (VAN DEN INGH et al., 2006). In contrast, the hepatic granulomas are findings of great relevance in CVL, having been widely described (MELO et al., 2009; MOREIRA et al., 2016; SANT'ANA et al., 
2007). Granulomatous hepatitis in dogs may be a response to either hepatic or extra-hepatic processes. Considering that Leishmania infection typically leads to granuloma formation and due to the fact that all dogs from this study had confirmed visceral leishmaniasis, we hypothesized that the granulomatous inflammation herein reported is related to the host response to the this infection (ROTHUIZEN et al., 2006); however, other infectious and noninfectious causes cannot be ruled out.

In the course of leishmaniasis, granulomas are associated with the resolution and clearance of the liverinfectioninthemurinemodel(LOEUILLETetal., 2016) and allow local concentration of inflammatory cytokines that activate the leishmanicidal mechanisms of Kupffer cells (SRIVASTAVA et al., 2016), which may explain the higher IFN- $\gamma$ median found in samples with granuloma. Although, there are other causes for hemosiderin presence, this finding in the liver was previously reported in CVL (SANT'ANA et al., 2007), and possibly the low nitric oxide production in symptomatic animals is associated with higher rates of iron deposition on tissue (SOUZA et al., 2014), which corroborates our results. Moreover, evidence suggested that symptomatic dogs present increased lipid peroxidation and tissue iron deposition associated with enhanced levels of antioxidant enzymes; and therefore, these changes in the oxidative balance may aggravate the pathological process in CVL (SOUZA et al., 2014). Interestingly, SOUZA et al. (2014) also evidenced hepatic fibrosis associated with the presence of antioxidant enzymes and MELO et al. (2008) reported fibrotic process, both in naturally infected dogs; however, such alteration was not evident in any of the animals in this research.

Although MOREIRA et al. (2016), verified greater parasite density in the spleen in comparison with liver, our results revealed no significant difference, indicating a positive correlation between these organs and their parasite loads; however, a comprehensive study including the assessment of immunological markers in other target tissues and in the peripheral blood, as well as the investigation of overlapping diseases, is necessary to improve the understanding on the overall immune response in these animals. This is particularly relevant considering that the dogs herein included were naturally infected and there was no clinical history available.

It is important to highlight that the parameters evaluated in this study may vary throughout the infectious process, as presented in the experimental research with the canine model (COSTA et al., 2013). In this context, our results generated new data and pave the way for the future clinical, parasitological, and immunological monitoring of dogs naturally infected by $L$. infantum in the field.

\section{CONCLUSION}

It is suggested that IFN- $\gamma$ and IL- 6 can present a balance between the attempt to Th1 pathway parasitic elimination and the active disease, thus highlighting the possible anti-inflammatory role of IL6. IL-4 apparently contributes to parasite persistence, as well as the low or no detection of IL-12 and iNOS. The liver was the main cytokine-producing organ, and hepatic IL-10 suggests a regulatory accompaniment, whereas the splenic response is suggested as sub optimized, due to the tissue changes and deficiency in the cell interaction. We concluded that the parasite load, tissue damage, and immunological response may present different comportments even in the presence of the same clinical status, which may not be a good criterion for assessing dog susceptibility.

\section{ACKNOWLEDGEMENTS}

This study was supported by Coordenação de Aperfeiçoamento de Pessoal de Nível Superior (CAPES), process 99999.000250/2014-07, related to TCBV, Fundação de Amparo à Pesquisa do Estado do Rio de Janeiro (FAPERJ) - Jovem Cientista do Nosso Estado, Code E-26/201.495/2014, related to FBF and Project PAEF/Instituto Oswaldo Cruz (IOC) Code IOC008-FIO-15, related to FCS. FBF holds a grant from $\mathrm{CNPq}$ for productivity in research. The funders had no role in study design, data collection, analysis and interpretation of data, decision to publish, or preparation of the manuscript.

\section{ETHICAL APPROVAL}

The project underwent ethical review and was approved and registered by the Ethics Committees on the Use of Animals in Research under the numbers LW-47/12 Fundação Oswaldo Cruz (FIOCRUZ) and 688 Universidade Federal Fluminense (UFF), Rio de Janeiro state, Brazil.

\section{DECLARATION OF CONFLICT OF INTERESTS}

The authors declare no conflict of interest. The founding sponsors had no role in the design of the study; in the collection, analyses, or interpretation of data; in the writing of the manuscript, and in the decision to publish the results.

\section{AUTHOR CONTRIBUTIONS}

TCBV (Conceptualization; Data Curation; Investigation; Methodology; Writing - Original Draft Preparation); SFB (Supervision; Writing - Review and Editing); LHMM (Investigation; Data Curation; Methodology; Writing - Review and Editing); FCS (Writing - Review and Editing); VSB (Formal Data 
Analysis); FBF (Conceptualization; Methodology; Supervision; Writing - Review and Editing).

\section{REFERENCES}

ALMEIDA, A.B.P.F. et al. Use of parasitological culture to detect Leishmania (Leishmania) chagasi in naturally infected dogs. Vector Borne Zoonotic Diseases, v.12, p.1555-1560, 2011. Available from: <https://doi.org/10.1089/vbz.2011.0723>. Accessed: Mar. 20, 2012. doi:10.1089/vbz.2011.0723.

BORJA, L.S. et al. Parasite load in the blood and skin of dogs naturally infected by Leishmania infantum is correlated with their capacity to infect sand fly vectors. Veterinary Parasitology, v.229, p.110-117, 2016. Available from: <https://doi.org/10.1016/j. vetpar.2016.10.004>. Accessed: Oct. 31, 2016. doi: 10.1016/j. vetpar.2016.10.004.

BRASIL, 2009. Guia de vigilância epidemiológica, $7^{\mathrm{a}}$ ed. Brasília: Ministério da Saúde.

CAVALCANTI, A.S. et al. Parasite load induces progressive spleen architecture breakage and impairs cytokine mRNA Expression in Leishmania infantum-naturally infected dogs. PLoS ONE, v.10 (4), e0123009, 2015. Available from: <https://doi.org/10.1371/ journal.pone.0123009>. Accessed: Jan. 24, 2017. doi:10.1371/ journal.pone.0123009.

CECÍLIO, P. et al. Deception and manipulation: the arms of Leishmania, a successful parasite. Frontiers in Immunology, v.5, p.480, 2014. Available from: <https://doi.org/10.3389/ fimmu.2014.00480>. Accessed: Feb. 24, 2015. doi: 10.3389/ fimmu.2014.00480.

CORRÊA, A.P.F.L. et al. Evaluation of transformation growth factor $\beta 1$, interleukin- 10 , and interferon- $\gamma$ in male symptomatic and asymptomatic dogs naturally infected by Leishmania (Leishmania) chagasi. Veterinary Parasitology, v.143, p.267-274, 2007. Available from: <http://dx.doi.org/10.1016/j.vetpar.2006.08.023>. Accessed: Jul. 26, 2013. doi: 10.1016/j.vetpar.2006.08.023.

COSTA, D.J. et al. Experimental infection of dogs with Leishmania and saliva as a model to study Canine Visceral Leishmaniasis. PloS One. v.8(4), 2013. Available from: <https://doi.org/10.1371/ journal.pone.0060535>. Accessed: Dec. 4, 2013. doi: 10.1371/ journal.pone. 0060535 .

DANTAS-TORRES, F. Canine leishmaniosis in South America. Parasites and Vectors, v.2 (1), S1, 2009. Available from: $<\mathrm{https}: / /$ doi.org/10.1186/1756-3305-2-S1-S1>. Accessed: Jul. 21, 2013. doi: 10.1186/1756-3305-2-S1-S1.

DA SILVA, A.V.A. et al. Morphophysiological changes in the splenic extracellular matrix of Leishmania infantum-naturally infected dogs is associated with alterations in lymphoid niches and the CD4+ T cell frequency in spleens. PLoS neglected tropical diseases, v.12, n.4, p.e0006445, 2018. Available from: <https:// doi.org/10.1371/journal.pntd.0006445>. Accessed: May, 25, 2019. doi: 10.1371/journal.pntd.0006445.

DE LIMA, V.M.F. et al. IL-6 and TNF-a production during active canine visceral leishmaniasis. Veterinary Immunology and Immunopathology, v.115, p.189-193. Available from: <https:// doi.org/10.1016/j.vetimm.2006.10.003>. Accessed: Jul. 25, 2013. doi: 10.1016/j.vetimm.2006.10.003.
DE MENEZES, J.P. et al. The site of the bite: Leishmania interaction with macrophages, neutrophils and the extracellular matrix in the dermis. Parasites and Vectors, v.9, n.264, 2016. Available from: <https://doi.org/10.1186/s13071-016-1540-3>. Accessed: Jan. 25, 2017. doi: 10.1186/s13071-016-1540-3.

DE VASCONCELOS, T.C.B. et al. Cytokine and iNOS profiles in lymph nodes of dogs naturally infected with Leishmania infantum and their association with the parasitic DNA load and clinical and histopathological features. Veterinary Parasitology, v.227, p. 8-14, 2016. Available from: <https://doi.org/10.1016/j. vetpar.2016.07.017>. Accessed: Aug. 25, 2016. doi: 10.1016/j. vetpar.2016.07.017

DOS SANTOS, I.B. et al. Higher sensitivity of immunohistochemistry for bona fide diagnosis of dog Leishmania (Viannia) braziliensis - driven American tegumentary leishmaniasis: description of an optimized immunohistochemistry method. Transactions of the Royal Society of Tropical Medicine and Hygiene, v.109, p.469-476, 2015. Available from: <https:// doi.org/10.1093/trstmh/trv034>. Accessed: Jan. 25, 2017. doi: $10.1093 / \mathrm{trstmh} / \mathrm{trv} 034$.

DOS SANTOS, P.L. et al. The Severity of Visceral Leishmaniasis Correlates with Elevated Levels of Serum IL-6, IL-27 and sCD14. PLOS Neglected Tropical Diseases, v.10 (1), e0004375, 2016. Available from: <https://doi.org/10.1371/journal.pntd.0004375>. Accessed: Jan. 25, 2017. doi: 10.1371/journal.pntd.0004375.

ENGWERDA, C.R. et al. Macrophages, pathology and parasite persistence in experimental visceral leishmaniasis. Trends in parasitology, v.20, n.11, p.524-530, 2004. Available from: $<$ https://doi.org/10.1016/j.pt.2004.08.009>. Accessed: May. 25, 2019. doi:10.1016/j.pt.2004.08.009.

GRADONI, L. Canine Leishmania vaccines: Still a long way to go. Veterinary Parasitology, v.208, p.94-100, 2015. Available from: $<$ https://doi.org/10.1016/j.vetpar.2015.01.003>. Accessed: Apr. 20, 2015.doi: 10.1016/j.vetpar.2015.01.003.

HEGDE, S. et al. Novel immunosuppressive properties of interleukin-6 in dendritic cells: inhibition of NF-kappaB binding activity and CCR7 expression. FASEB Journal, v.18, n.12, p.1439-41, 2004. Available from: <https://doi.org/10.1096/fj.030969fje>. Accessed: Feb. 20, 2017. doi: 10.1096/fj.03-0969fje.

HERMIDA, M.R. et al. Histological disorganization of spleen compartments and severe visceral leishmaniasis. Frontiers in Cellular and Infection Microbiology, v.8, 2018. Available from: $<$ https://doi.org/10.3389/fcimb.2018.00394>. Accessed: May, 20, 2019. doi: $10.3389 /$ fcimb.2018.00394.

KAYE，P.M.; BEATTIE, L. Lessons from other diseases: granulomatous inflammation in leishmaniasis. In: Seminars in immunopathology. Springer Berlin Heidelberg, 2016, p.249-260. Available from: <https://doi.org/10.1007/s00281-015-0548-7>. Accessed: May, 27, 2019. doi: 10.1007/s00281-015-0548-7.

LAGE, R.S. et al. Analysis of the cytokine profile in spleen cells from dogs naturally infected by Leishmania chagasi. Veterinary Immunology and Immunopathology, v.115 (1-2), p. 135-145, 2007. Available from: <https://doi.org/10.1016/j. vetimm.2006.10.001>. Accessed: Jul. 20, 2013. doi: 10.1016/j. vetimm.2006.10.001 
LIMA, I.S. et al. Severe Clinical Presentation of Visceral Leishmaniasis in Naturally Infected Dogs with Disruption of the Splenic White Pulp. PLoS ONE, v.9, n.2, e87742, 2014. Available from: <https://doi.org/10.1371/journal.pone.0087742>. Accessed: Jul. 25, 2015.doi:10.1371/journal.pone.0087742.

LIU, D.; UZONNA, J.E. The early interaction of Leishmania with macrophages and dendritic cells and its influence on the host immune response. Frontiers in Cellular and Infection Microbiology, v.2, 83, 2012. Available from: <https://doi. org/10.3389/fcimb.2012.00083>. Accessed: Jun. 23, 2015. doi: $10.3389 /$ fcimb.2012.00083

LOEUILLET, C. et al. Study of Leishmania pathogenesis in mice: experimental considerations. Parasites and Vectors, v.9, 144, 2016. Available from: <https://doi.org/10.1186/s13071-016-14139>. Accessed: Jan. 23, 2017. doi: 10.1186/s13071-016-1413-9.

MAIA, C.; CAMPINO, L. Cytokine and Phenotypic Cell Profiles of Leishmania infantum infection in the Dog. Journal of Tropical Medicine, p.1-7, 2012. Available from: <http:// dx.doi.org/10.1155/2012/541571>. Accessed: Jul. 27, 2013. doi:10.1155/2012/541571.

MANCIANTI, F. et al. Studies on canine control: Evolution of infection of different clinical forms of canine leishmaniasis following antimonial treatment. Transactions of the Royal Society of Tropical Medicine and Hygiene, v.82, p.566567, 1988. Available from: <https://doi.org/10.1016/00359203(88)90510-X>. Accessed: Jul. 27, 2013. doi: 10.1016/00359203(88)90510-X.

MELO, F.A. et al. Hepatic extracellular matrix alterations in dogs naturally infected with Leishmania (Leishmania) chagasi. International Journal of Clinical and Experimental Pathology, v.90, n.5, p. 538-548, 2009. Available from: <https://doi.org/10. 1111/j.1365-2613.2009.00681.x>. Accessed: Jul. 25, 2013. doi: 10.1111/j.1365-2613.2009.00681.x.

MELO, F.A. et al. Diffuse intralobular liver fibrosis in dogs naturally infected with Leishmania (Leishmania) chagasi. The American Journal of Tropical Medicine and Hygiene, v.79, n.2, p.198-204, 2008. Available from: <https://www.ncbi.nlm.nih.gov/ pubmed/18689624>. Accessed: Jul. 25, 2013.

MICHELIN, A.F. Evaluation of TNF- $\alpha$ IL-4, and IL-10 and parasite density in spleen and liver of $L$. (L.) chagasi naturally infected dogs. Annals of Tropical Medicine \& Parasitology, v.105, p. 1-12, 2011. Available from: <https://doi.org/10.117 9/1364859411Y.0000000027>. Accessed: Jul. 25，2013. doi: 10.1179/1364859411Y.0000000027.

MOREIRA, P.R.R. et al. Influence of apoptosis on liver and spleen resistance in dogs with visceral leishmaniosis. Brazilian Journal of Veterinary Parasitology, v.25, n.3, p.341-347, 2016. Available from: <http://dx.doi.org/10.1590/S1984-29612016054>. Accessed: Jan. 26, 2017. doi: 10.1590/S1984-29612016054.

NASCIMENTO, M.S.L. et al. Naturally Leishmania infantuminfected dogs display an overall impairment of chemokine and chemokine receptor expression during visceral leishmaniasis. Veterinary immunology and immunopathology, v.153, n.34, p.202-208, 2013. Available from: <https://doi.org/10.1016/j. vetimm.2013.02.015>. Accessed: May, 15, 2019. doi: 10.1016/j. vetimm.2013.02.015.
NYLÉN, S.; KUMAR, R. Immunobiology of visceralleishmaniasis. Frontiers in Immunology, v.3, 251, 2012. Available from: $<$ https://doi.org/10.3389/fimmu.2012.00251>. Accessed: Jul. 26, 2015. doi: 10.3389/fimmu.2012.00251.

RODRIGUES, V. et al. Regulation of immunity during visceral Leishmania infection. Parasites and Vectors. v.9, 118, 2016. Available from: <https://doi.org/10.1186/s13071-016-1412-x $>$. Accessed: Jan. 26, 2017. doi: 10.1186/s13071-016-1412-x.

ROTHUIZEN, J. et al. Hepatic abscesses and granulomas, hepatic metabolic storage disorders and miscellaneous conditions. In: WSAVA standards for clinical and histological diagnosis of canine and feline liver disease. Saunders Elsevier, Edinburgh, UK, 2006, p. 103-105.

SANT'ANA, C.C. et al. Inflammation and structural changes of splenic lymphoid tissue in visceral leishmaniasis: a study on naturally infected dogs. Parasite Immunology, v.30, n.10, p. 515-524, 2008. Available from: <https://doi.org/10.1111 /j.1365-3024.2008.01051.x>. Accessed: Jul. 25, 2013. doi: 10.1111/j.1365-3024.2008.01051.x.

SANT'ANA, J.A.P. et al. Hepatic granulomas in canine visceral leishmaniasis and clinical status. Arquivo Brasileiro de Medicina Veterinária e Zootecnia. v.59, n.5, p.1137-1144, 2007. Available from: <http://dx.doi.org/10.1590/S0102-09352007000500008>. Accessed: Jul. 25, 2013. doi: 10.1590/S0102-09352007000500008.

SCHELLER, J. et al. The pro- and anti-inflammatory properties of the cytokine interleukin-6. Biochimica et Biophysica Acta, v.1813, p.878-888, 2011. Available from: <https://doi. org/10.1016/j.bbamcr.2011.01.034>. Accessed: Jul. 15, 2013. doi: 10.1016/j.bbamcr.2011.01.034.

SOUZA, C.C. et al. A potential link among antioxidant enzymes, histopathology and trace elements in canine visceral leishmaniasis. International Journal of Experimental Pathology, v.95, p.260 270, 2014. Available from: <https://www.ncbi.nlm.nih.gov/pmc/ articles/PMC4170968/>. Accessed: Jan. 29, 2017. doi: 10.1111/ iep. 12080 .

SRIVASTAVA, S. et al. Possibilities and challenges for developing a successful vaccine for leishmaniasis. Parasites and Vectors, v.9, 277, 2016. Available from: <https://doi.org/10.1186/s13071-0161553-y>. Accessed: Jan. 29, 2017. doi: 10.1186/s13071-016-1553-y.

STRAUSS-AYALIA, D. et al. Splenic immune responses during canine visceral leishmaniasis. Veterinary Research. v.38, p. 547-564, 2007. Available from: <https://doi.org/10.1051/ vetres:2007015>. Accessed: Jul. 25, 2013.doi: 10.1051/ vetres:2007015

SUNDAR, S; RAI, M. Laboratory Diagnosis of Visceral Leishmaniasis. Clinical and diagnostic laboratory immunology. p. 951-958, 2002. Available from: <https://www.ncbi.nlm.nih. gov/pmc/articles/PMC120052/pdf/0013.pdf > . Accessed: Mar. 11, 2019. doi: 10.1128/CDLI.9.5.951-958.2002.

TASCA, K.I. et al. Exames parasitológicos, imunoistoquímicos e histopatológicos para detecção de Leishmania chagasi em tecidos esplênicos de cães com leishmaniose visceral. Brazilian Journal of Veterinary Parasitolology, v.18, n.1, p.27-33, 2009. Available from: <http://dx.doi.org/10.4322/rbpv.01801005>. Accessed: Jul. 25, 2013. doi: $10.4322 /$ rbpv. 01801005 . 
TORRES, M.M. et al. Hemostatic assessment of dogs associated with hepatic parasite load of Leishmania infantum chagasi. Brazilian Journal of Veterinary Parasitolology, v.25, n.2, p.244247, 2016. Available from: <http://dx.doi.org/10.1590/S198429612016036>. Accessed: Jan. 28, 2017. doi: 10.1590/S198429612016036.

TRINCHIERI, G. Interleukin-10 production by effector $\mathrm{T}$ cells: Th1 cells show self control. Journal of Experimental Medicine, v.204, n.2, p.239-243, 2007. Available from: <http:// doi.org/10.1084/jem.20070104>. Accessed: Jul. 28, 2013. doi: $10.1084 /$ jem.20070104.

VAN DEN INGH, T.S. et al. Morphological classification of parenchymal disorders of the canine and feline liver. WSAVA
Standards for clinical and histological diagnosis of canine and feline liver disease, p.85-101, 2006.

WANASEN, N.; SOONG, L. L-arginine metabolism and its impact on host immunity against Leishmania infection. Immunology Research, v.41, n.1, p.15-25. Available from: $<$ https://link.springer.com/article/10.1007/s12026-007-8012-y>. Accessed: Jul. 28, 2013. doi: 10.1007/s12026-007-8012-y.

WERNECK, G.L. Visceral leishmaniasis in Brazil: rationale and concerns related to reservoir control. Revista de Saúde Pública. v.48, n.5, p.851-855, 2014. Available from: $<$ http://dx.doi.org/10.1590/S0034-8910.2014048005615>. Accessed: Apr. 01, 2015. doi: 10.1590/S00348910.2014048005615. 